\title{
iMKB'de İşlem Gören İşletmeler için Para Politikası ve Sermaye Yapısı İlişkisi
}

\author{
The Relationship Between Monetary Policy and Capital Structure for Companies Traded \\ in Istanbul Stock Exchange
}

Umut HALAÇ ${ }^{1}$, Mustafa Gürol DURAK ${ }^{2}$

\section{ÖZET}

Genişleyen para politikasından yararlanmak isteyen işletmeler göz önüne alındığında borsada işlem görmeyen işletmelerin yatıımlarını artırmaları için otofinansman dışındaki tek yol düşük faiz oranlarından borçlanmaktır. Borsada işlem gören işletmelerin yararlanabileceği bir başka seçenek ise hisse senedi ihraç etmektir. Bu işletmeler, yatırıma yönlendirecekleri tutarları yeni hisse senedi ihracı yoluyla elde edebilirler veya düşük faiz oranlarıyla borçlanma olanaklarından yararlanmak isteyebilirler. Bu durum Tobin q teorisi ile açıklanmaktadır.

Tobin q teorisi, para politikasının menkul kıymetler borsası kanalıyla ekonomiyi etkileme mekanizmasını açıklamaktadır. Tobin $q$, işletmelerin piyasa değerlerinin sermayenin yerine konma maliyetine bölünmesi olarak tanımlanmaktadır. Şayet "q" değeri yükssek ise, firmanın piyasa fiyatı göreceli olarak sermayenin yerine konma maliyetinden büyüktür. Bu durumda işletmeler hisse senedi arz ederek, yeni yatırımın maliyetinden göreceli olarak daha yüksek getiri elde edebilmektedirler. Az miktarda hisse senedi arzı ile daha fazla yatırım yapılabilmekte; böylece toplam yatırım tutarı artabilmektedir.

Bu çalışmanın amacı, 2003-2010 yılları arasında İstanbul Menkul Kıymetler Borsası'nda (IMKB) işlem gören şirketlerin, para politikalarını da göz önünde bulundurarak yatıımlarının finansmanında hangi yöntemi tercih ettiklerini incelemektir. Inceleme kapsamında önceki dönemlerin sermaye yapılarının da etkisini göz önünde bulundurabilmek üzere Arellano-Bond dinamik panel veri tahminleme yöntemi yardımı ile analiz gerçekleştirilmiştir. Oluşturulan modelin test edilmesi sonucunda borç/öz kaynak geçmiş dönem değerlerinin ve Tobin q değişkenlerinin olası finansman kararlarında etkili olmadığı, öte yandan Türk lirası faiz oranı, üretici fiyat endeksi, Avro kaynaklı borçlanma riski değişkenlerinin işletmelerin finansman kararlarında etkili oldukları tespit edilmiştir.

Anahtar Kelimeler: Tobin q, para politikası, sermaye yapısı

\section{GiRiş}

İktisat literatüründe sermaye kavramı değişik şekillerde ele alınmaktadır. Genel olarak sermaye, işletmelerin ekonomik fayda sağlamak üzere kullandıkları ve bilançonun aktif kısmını oluşturan varlıklar ile bu varlıkların edinilmeleri için işletme dışından sağlanan, uzun ve kısa vadeli yabancı kaynaklar arasındaki fark olarak tanımlanmaktadır. İşletme yöneticileri bu

\begin{abstract}
For the companies not quoted into the stock exchange the only way to finance their investments other than using autofinancing is to borrow with lower interest rates under expansionary monetary policy. On the other hand, for the quoted companies, there is one more option; issuing new common stocks. These companies can direct the funds to investments either by issuing new stocks or enjoying lower interest rate opportunities. This situation is explained as Tobin's q theory.

Tobin's q theory defines the mechanism that monetary policy affects the economy throughout the stock exchange. Tobin $q$ is calculated as market value of firms divided by replacement cost of their assets. If $q$ is high, the relative market value of the company is higher than its replacement cost. Companies can get relatively higher returns on their stocks compared to the cost of new investment by issuing new stocks. They can make more investment by issuing lower numbers of stocks; therefore total investment probably increases.

The aim of this study is to investigate the preferences of companies that are quoted to Istanbul Stock Exchange (ISE) for the years 2003-2010, in financing their investments considering the monetary policies. In the context of investigation, Arellano-Bond dynamic panel data methodology is applied in order to consider the lagged values of capital structures, as well. On the base of the constructed model, Tobin $q$ and lagged value of debt/equity variables don't have any significant effect on the financing decision of the firm, whereas interest rate on Turkish Lira, Producer Price Index, exposure risk of Euro are significant in model.
\end{abstract}

Keywords: Tobin's q, monetary policy, capital structure

varlıkların kullanımında izledikleri politikalar ile işletme değerine etki edebilmektedirler. Ancak varlıkların doğru ve etkin kullanımı işletme performansının artmasına yardımcı olmasına karşın işletmeyi en yüksek değerine ulaştırmak için yeterli değildir. Bu noktada yöneticilerin varlık edinimine yönelik olarak uyguladıkları finansman politikalarına da dikkat etmek gerekmektedir. Finansman politikası ya borçlanma ya 
da öz kaynaklardan yararlanma yoluyla kaynak sağlama şeklinde gerçekleşmektedir. Kullanılan kaynakların kendi içerisindeki birleşimi sermaye yapısı olarak isimlendirilmektedir. Diğer bir ifadeyle, işletmeler tarafından kullanılan farklı türde finansal kaynakların göreceli tutarlarına sermaye yapısı adı verilmektedir.

Literatürde sermaye yapısına ilişkin pek çok çaış̧ma yapılmış olmakla birlikte, sermaye yapısının işletme değeri üzerindeki etkilerinin incelendiği çalışmalar ön plana çıkmış durumdadır. Özellikle Modigliani ve Miller (1958) tarafından ortaya atılan görüş ve buna karşı savunulan diğer görüşler doğrultusunda ekonomi ve finans literatüründe birçok yaklaşım ve teoriler ortaya çıkmıştır. Modigliani ve Miller (1958) sermaye yapısının işletme değeri üzerinde etkisinin bulunmadığını belirtmiş̧tir. Bu görüşü ortaya atarken temel aldıkları varsayımlar şu şekilde sıralanmaktadır; i) işlem maliyetleri, iflas maliyetleri, vergi ve enflasyon yoktur, ii) borçlanma ve borç verme faizleri eşittir, iii) finansman ve yatırım kararları birbirinden bağımsızdır.

İzleyen dönemlerde, bu varsayımların geçerli olmadıkları ve sermaye yapılarının belirlenmesinde göz önünde bulundurulması gereken ekonomik çevreyi tam yansıtmadıkları görüşü yaygınlaşmıştır. Ortaya konan teoriler ile sermaye yapısını belirleyici etkenler incelenmeye çalışılmış ve değişik görüşler ortaya atılmıştır. Iş̧letmelerin mikro bazda ele alınan (işletmeye özgü) özelliklerinin finansman politikalarının belirlenmesinde etkisinin bulunduğu pek çok çalışmada ortaya konulmuştur. Ancak, genel ekonomik çevrede mevcut bulunan şartların etkisinin incelendiği çalışmalara pek rastlanmamaktadır.

Daha önce de belirtildiği gibi sermaye yapısının belirlenmesinde işletmeye özgü özellikleri ortaya koymayı amaçlayan çalışmalar yapılmasına rağmen, bu belirlemede rol oynaması beklenen para politikası gibi makroekonomik değişkenlerin kullanıdığı çalışmalara rastlanmamaktadır. Bu çalışmada, literetüre sözü edilen eksiklik konusunda bir ölçüde katkıda bulunabilmek amaçlanmakta ve sermaye yapısının belirlenmesine yönelik olarak ortaya çıkan teoriler ışığında para politikalarının işletmelerin sermaye yapıları üzerindeki etkisi incelenmektedir. Bu doğrultuda çalışmanın ikinci bölümünde Modigliani ve Miller'ın (1958) ardından ortaya atılan ve sermaye yapılarının belirlenmesinde etkili olan dinamiklerin ele alındığı teoriler açıklanmaktadır. Üçüncü bölümde para politikasını ve işletmelerin sermaye yapılarını doğrudan etkileyen parasal aktarım mekanizmaları ele alınmakta ve bunların sermaye yapısı ile ilişkisi açıklanmaktadır. Dördüncü bölümde Türkiye'de bu ilişkinin ne yönde gerçekleştiği araştırılmakta ve bu doğrultuda elde edilen bulgulara yer verilmektedir. Çalışmanın beşinci bölümünde ise bulgular değerlendirilmektedir.

\section{SERMAYE YAPISININ BELIRLEYICILERI}

Modigliani-Miller (1958)'i takip eden birkaç farkIı teori ortaya atılmıştır (Buferna vd., 2005; Akkaya, 2008). Bunlardan ilki "Dengeleme Teorisi"dir (Tradeoff Theory). Dengeleme teorisi, ek finansman yükünün işletmeye getireceği vergi avantajı ile iflas maliyetlerinin dengelenerek optimum sermaye yapısının belirlenmesi üzerine kurulmuştur. Bu durumda optimum sermaye yapısı, sermaye maliyetini en aza indirerek işletmenin değerini en yükseğe çıkaran sermaye yapısıdır. İşletmeler için marjinal maliyetler ile marjinal gelirlerin dengelendiği sermaye yapısı olarak da ifade edilmektedir (Frank ve Goyal, 2007). Dengeleme teorisinin temelini oluşturan iki konu borçlanmanın getirdiği vergi avantajı ve artan finansal riskin neden olduğu iflas maliyetleridir. Borçlanma sonucu ortaya çıkan faiz ödemeleri gider olarak kaydedilmekte ve bu durum ödenecek vergiyi azaltmaktadır. Buna karşılık kar paylarının gider olmaması, borçlanmanın öz sermaye yoluyla finansmana göre daha az maliyetli olmasına neden olmaktadır. Ancak Miller (1977), dengeleme teorisinde ele alınan bu vergi avantajının, elde edilen faiz gelirleri ve kar payları üzerinden ödenmesi gereken bireysel gelir vergileri de göz önünde bulundurulduğunda ortadan kalktığını, hatta tam tersi bir etki yarattığını belirtmektedir. Öte yandan, işletmenin fazla borçlanması geri ödeyememe ve beraberinde iflas riskini ortaya çıkarmaktadır. Bu risk işletmeye iflas maliyetleri olarak yansımaktadır. Borçlanma sonucu artan finansal risk nedeniyle borç verenler ve hissedarlar daha yüksek prim talep etmektedirler. Bu talepleri karşılamak üzere işletmelerin katlanmak zorunda kaldığı maliyetler de iflas maliyetlerini oluşturmaktadır. İflas maliyetleri "dolaylı" ve "doğrudan" maliyetler olmak üzere iki sınıfta ele alınmaktadır. Doğrudan iflas maliyetleri avukatlık ücretleri gibi, üçüncü şahıslara yapılan yasal ödemeleri içermektedir. Dolaylı iflas maliyetleri ise bozulan müşteri ve tedarikçi ilişkileri, kaybedilen iyi işgücü/yönetici, kredi bulmada yaşanan zorluklar gibi etkenleri içermektedir.

Dengeleme teorisinin firma davranışlarını ve piyasanın işletmenin kullandığı finansal kaldıraca ne şekilde tepki vereceğini açıklama konularında eksik kaldığını savunan Myers ve Majluf (1984) "Finansal Hiyerarşi Teorisi"ni (Pecking Order Hypothesis) or- 
taya koymuştur. Bu teori temel olarak yöneticiler ile finansal bilginin dışsal kullanıcıları arasındaki asimetrik bilgiye dayanmaktadır. Myers ve Majluf (1984)'a göre yöneticiler, ellerindeki asimetrik bilgiyi kullanarak, hisse senetlerinin aşırı değerlendiği dönemlerde hisse senedi ihraç etmektedirler. Yatırımcıların da bu durumun farkında oldukları, bu nedenle işletmenin mevcut ve yeni hisselerinin fiyatını düşürecek şekilde davranacakları düşünülmektedir. Bu nedenle yöneticiler, özellikle yeni hisse ihracı gerekiyorsa, karlı yatırımlardan vazgeçebilmektedirler. Bu durumu engellemek için yöneticilerin ilk tercihi hiç asimetrik bilgi içermeyen oto finansman olmaktadır. Diğer bir deyişle, ilk finansman kaynağı dağıtılmamış karlardır. Ardından nispeten daha az asimetrik bilgi içeren düşük riskli borçlanma araçları kullanılmaktadır. Yatırımı karşılamak için bu da yeterli olmazsa, daha riskli borçlanma araçları ve en son olarak hisse senedi ihraCı yolu tercih edilmektedir. Ayrıca ödenmesi gereken harçlar, ihraç maliyetleri, bilgilendirme maliyetleri vb. maliyetler de borçlanmayı hisse senedi ihracından önce tercih edilecek bir finansman yöntemi yapmaktadır (Fama ve French, 2002; Drobetz ve Fix, 2003).

Myers (1984), riskli finansal araçlar ihraç etmenin maliyetinin dengeleme modelindeki optimum sermaye yapısının belirleyicilerinden daha baskın olduğunu belirtmektedir. Bu nedenle Finansal Hiyerarşi Teorisi'nde optimum kaldıraç oranı bulunmamakta, her işletme yatırımın büyüklüğü, karlıığı gibi faktörlere göre bu oranı belirlemektedir. Örneğin yüksek karlılığa sahip işletmeler finansman ihtiyaçlarını elde ettikleri karlardan karşılayabildikleri için borçlanma ihtiyaçları düşük karlılığa sahip işletmelere göre daha azdır. Bu nedenle, işletmelerin karlılıkları arttıkça kullandıkları kaldıraç azalmaktadır (Gupta, 1969; Myers, 1977; Akkaya, 2008). Uygulamaya dayalı çalışmalar uzun vadede dengeleme teorisinin daha yararlı olduğunu ancak kısa vadede finansal hiyerarşi teorisinin üstün olduğunu göstermektedir (Hovakimian vd., 2001).

Modigliani-Miller (1958) teorisini takiben ortaya çıkan bir diğer teori de Temsil Maliyetleri Teorisi (Agency Cost Theory)'dir. Temsil maliyetlerine yöneticiler ile hissedarlar arasında, hissedarlar ile alacaklılar arasında sadece mevcut ve potansiyel hissedarlar arasında ortaya çıkan çıkar çatışmaları neden olmaktadır. Mevcut hissedarlar sahip oldukları asimetrik bilgiyi kullanarak yüksek getirili bir yatırımın finansmanı için yeni hisse ihraç etmek yerine borçlanma yolunu seçebilmektedirler. Bunun nedeni getiriyi yeni ortaklarla paylaşmayı istememeleridir (Ata ve Ağ, 2010).
Öte yandan, temsil sorunu "finansman-yönetim ayrılı̆ı" ya da "sahiplik-kontrol ayrılığı" olarak da tanımlanmaktadır. Hissedarların fon sağlayan taraf, yöneticilerin (temsilcinin) de bu fonları yatırımcının yararına kullanması beklenen taraf olmaları nedeniyle, yöneticiler kendi çıkarları doğrultusunda, ancak, hissedarların aleyhine davrandıklarında temsil maliyetleri ortaya çıkmaktadır (Uğurlu, 2000). Hissedarların yöneticileri kontrol altında tutmak üzere katlandıkları bu maliyetleri Jensen ve Meckling (1976) "izleme maliyetleri", "tazmin edici-garanti sağlayıcı anlaşma maliyetleri" ve "önlenemeyen kayıplar" olarak sınıflandırmaktadır. Hedef, yöneticilerin işletmenin serbest nakit akışlarını kendi çıkarları doğrultusunda getirisiz ya da düşük getirili projelerde kullanmalarını engellemektir (Jensen ve Meckling, 1976; Easterbrook, 1984; Jensen, 1986). Bu doğrultuda işletmeler, serbest nakit akışlarının zorunlu faiz ödemelerinde kullanılmalarını sağlamak için borçlanmayı tercih etmektedirler (Fama ve French, 2002).

Bunun yanı sıra, işletmenin hissedarları ile kredi verenlerin işletmeden beklentileri farklı olduğu için yatırım projelerinin değerlendirilmesi konusu da temsil maliyetine neden olmaktadır. Hissedarlar yüksek getiri sağlayacak riskli projelere yönelirken, kredi verenler alacaklarını garanti altına alacak riski düşük projeleri tercih etmektedirler. Bu nedenle, hissedarların aldıkları yüksek riske karşı kredi verenler yüksek faiz talep etmektedirler. Sonuç olarak firma değeri düşmektedir.

\section{PARA POLITIKASI VE SERMAYE YAPISI İLişKisi}

Maliye politikalarının ekonomiyi istenilen istikrar düzeyine ulaştırma konusunda etkinlikleri ve zamanlamaları açısından bazı şüpheler içermelerinden dolayı ekonomide arzulanan istikrarı sağlamak için para politikaları daha çok kullanılır hale gelmiştir. Para politikaları, parasal aktarım mekanizmaları olarak isimlendirilen kanallar aracılığıyla ekonominin geneline, dolayısıyla işletmelerin her türlü faaliyetlerine etki etmektedir.

Parasal aktarım mekanizmaları, "geleneksel faiz oranı kanalı" yöntemiyle literatüre girmiş, daha sonra "diğer varlık fiyatları kanalı" ve "kredi kanalı" literatürde yerini almıştır (Mishkin, 1996). Bu aktarım mekanizmalarını anlamak para politikasının ekonominin derinliklerine nasıl yayıldığını görmek ve etkilerini tahmin etmek açısından yararlı olacaktır. Ayrıca işletmelerin para politikasındaki değişikliklerden bu aktarım mekanizmaları yoluyla doğrudan ve dolaylı olarak nasıl etkileneceklerini anlamaları, kendi geleceklerine 
yön vermeleri açısından da oldukça önemlidir. Bu çaış̧mada şirketlerin sermaye yapılarını doğrudan etkileyen "geleneksel faiz kanalı" ve "diğer varlık fiyatları kanalının" altında yer alan "hisse senedi fiyat kanalı" parasal aktarım kanalları olarak ele alınacaktır. ${ }^{3}$

Geleneksel faiz oranı kanalı, parasal aktarım mekanizmalarının en çok bilinen kanalıdır. Bu aktarım mekanizmasına göre makroekonomik politika olarak genişleyici para politikası uygulandığında reel faiz oranlarının düşmesi beklenmektedir. Böylece sermaye maliyetlerini düşürerek daha fazla yatırım yapılmasına uygun bir ortam yaratılmış olmaktadır. İşletmelerin düşen borçlanma maliyetlerinden yararlanarak yatırımlarını artıracakları düşünülmektedir. Bu da işletmelerin sermaye yapılarında borçlanma kaleminin büyümesine ve borç/öz kaynak kaldıracının değerinin artmasına sebep olmaktadır. Diğer bir ifadeyle, düşen borçlanma maliyetleri işletmelerin sermaye yapılarını borçlanmanın ağırlığını artıracak şekilde etkilemektedir. Yatırımların artmasının sonucu olarak da toplam hasılanın yükselmesi beklenmektedir.

Diğer varlık fiyatları olarak adlandırılan aktarım mekanizması "döviz kuru kanalı" ve "hisse senedi kanalı" olmak üzere iki farklı alt kanalda incelenmektedir. Hisse senedi kanalı da kendi içerisinde "Tobin q teorisi", "servet etkisi" ve "ev fiyatları kanalı" olmak üzere üç alt kanalda ele alınmaktadır. Bu kanallardan sadece Tobin q teorisi işletmelerin sermaye yapısını doğrudan etkilediği için çalışmada bu kanalın incelenmesi uygun bulunmuştur. Tobin q teorisi, para politikasının hisse senedi değerlemesi yoluyla ekonomiyi nasıl etkilediğini incelemektedir. Tobin $q$, işletmelerin piyasa değerlerinin sermayenin yerine konma maliyetine oranı olarak tanımlanmaktadır (Tobin, 1969). Tobin q teorisi basitçe şu şekilde açıklanabilir: Genişleyici para politikası sonrası para arzının artmasıyla birlikte hane halkının elinde talep ettiğinden daha fazla para toplanacaktır. Bu fazlalığın yönlendirilebileceği seçeneklerden birisi menkul kıymetler borsası aracılığıyla hisse senetleridir. Hisse senetlerine olan talebin artması beraberinde hisse fiyatlarının yükselmesini getirecektir. Yükselen hisse senedi fiyatları "q" değerini yükseltecek ve işletmelerin daha fazla yatııım yapabilmeleri için uygun ortamın oluşturulmasına katkıda bulunacaktır. "q" değerinin 1'den yüksek olması, işletmenin piyasa değerinin sermayenin yerine konma maliyetinden daha yüksek olduğu anlamına gelmektedir. Bu durumda yeni yatırım veya sermaye yatırımı şirketin piyasa değeri ile karşılaştııılığı zaman göreceli olarak ucuzlamış gibi görünecektir. İşletmeler yeni hisse senedi ihracından geçmişe göre daha fazla para elde edebilecekler ve bu sayede daha maliyetli yatırımlar yapabileceklerdir. İşletmeler düşük oranda hisse senedi ihraç ederek birçok yeni yatırım malı satın alabilecekler, dolayısıyla toplam yatırım harcamaları artmış olacaktır. Toplam yatırımların artması, toplam hasılada bir artışın ortaya çıkmasına neden olacaktır.

Korajczyk, vd. (1990), işletmenin gerçek değerini yöneticilerin bilmesine rağmen piyasadaki yatırımcıların bilmediklerini, ancak bir süre sonunda, yanlış değerleme fark edilince, hisse senetlerinin gerçek değerine ulaşacağını belirtmektedirler. Diğer bir ifadeyle, Tobin q değerinin piyasanın değerlemesi ile alınacak yatırım kararları arasında doğrudan bir ilişki işaret ettiğini savunmaktadırlar. Buna göre gerçek değerinden yüksek değerlenen işletmelerin yöneticileri değerin düşmesine olanak vermeden hisse senedi ihraç etmek; düşük değerlenen işletmelerin yöneticileri ise hisse senetlerinin fiyatının gerçek değere kadar çıkmasını beklemek isteyeceklerdir. Korajczyk, vd. (1990) ile uyumlu olarak Korajczyk ve Levy (2002) hisse senetlerinin fiyatlarının yüksek artış gösterdiği dönemlerde işletmelerin borçla finansman yerine hisse senedi ihracı yolunu seçtiğini gözlemlemiştir.

Baker ve Wurgler (2002) tarafından ortaya atılan ve konuya davranışsal finans açısından yaklaşan Piyasa Zamanlama Teorisi (Market Timing Theory) temelde işletmelerin sermaye ihtiyaçlarını karşılamak üzere maliyetlerin en uygun olduğu finansman türünü seçtikleri varsayımına dayanmaktadır. Teoriye göre Tobin q değerinin yüksek olduğu dönemler aynı zamanda piyasa değeri - defter değeri oranının da yüksek olduğu dönemlere işaret etmektedir. Diğer bir ifadeyle, Tobin q değerinin yüksek olduğu dönemler işletmenin hisselerinin aşırı değerlendiği dönemler oldukları için işletme yöneticileri daha az hisse senedi ihraç ederek daha çok fon sağlayabileceklerdir. Tobin q değerinin düşük olduğu dönemlerde ise işletmenin piyasa değeri gerçek değerinden düşük olmakta ve bu nedenle hisselerin piyasadan geri satın alınması yöneticiler açısından doğru karar olarak nitelendirilmektedir.

Aynı şekilde, Kayhan ve Titman (2007) çalışmalarında finansal kaldıraç kullanımının piyasa zamanlama teorisi ile uyumlu bir şekilde değiştiğini kanıtlamaktadırlar. Hollanda firmaları üzerinde yaptıkları araştırma sonucunda Bie ve Haan (2007) da piyasa zamanlamasının etkisini belirlemekte ancak etkinin uzun vadeli bir süreğenliğine rastlamadıklarını ifade etmektedirler. Aynı sonuca G7 ülkeleri için Mahajan ve Tartaroglu (2007) ile Shenzhen piyasası için Tian, vd. (2008) de ulaşmışlardır. 


\section{MODEL VE METODOLOJi}

İktisat literatüründe para politikası, para arzının merkez bankası tarafından değiştirilmesi ile başlamaktadır. Türkiye'de 2005-2010 dönemine ait para arzı Grafik 1'de sunulmuştur. Grafikte, farklı para arzı tanımlarına göre (M1, M2 ve M3) para politikasındaki genişleme eğilimi göze çarpmaktadır. Dar para arzı tanımı olarak isimlendirilen $\mathrm{M} 1$ 'deki genişleme, diğer para arzı tanımlarının gösterdiği genişlemelerin yanında oldukça küçük kalmıştır. Ülkemizdeki parasal aktiviteleri değerlendirmek için sıklıkla başvurulan ve geniş para arzı olarak tanımlanan M2'deki genişleme eğilimi ise açık bir şekilde ortadadır. M3 para arzında da M2 para arzındaki artışa paralel bir hareket gözlenmektedir. İncelenen dönemde düzenli olarak parasal genişleme sağlandığı kolaylıkla söylenebilir. Bu durumda daha önce bahsedilen parasal aktarım mekanizması kanallarını, genişleyici para politikası bağlamında kurgulamak ve buna bağlı olarak modellemek yanlış olmayacaktır.

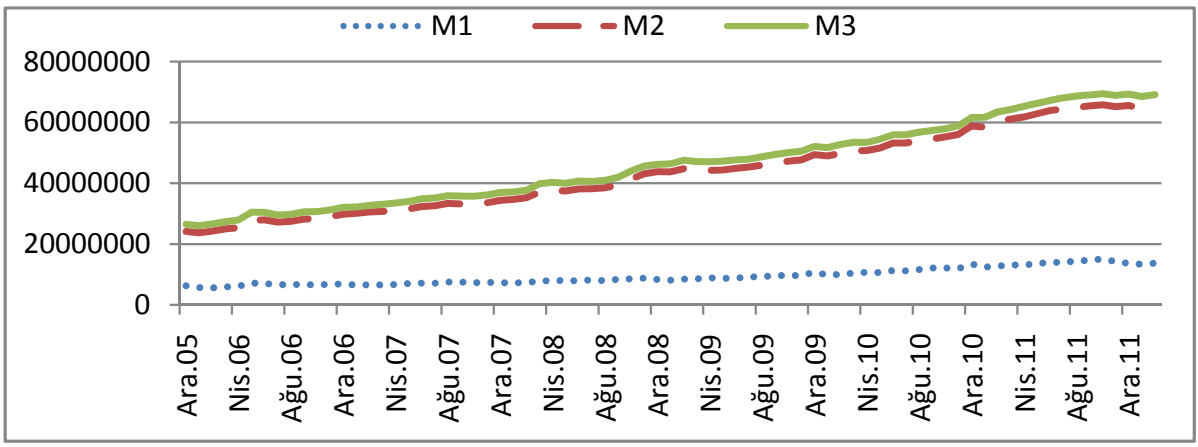

(Şekil 1: Para Arzı, Kaynak: T.C. Merkez Bankası)

Geniş̧leyici para politikasının sonucu olarak finansman ve yatırım faaliyetlerinde bulunmak isteyen işletmeler için hem geleneksel faiz oranı kanalının hem de Tobin q teorisi aracılığıyla değerlendirilen hisse senedi kanalının kullanımının mantıklı olduğu görülmektedir. Bu bağlamda işletmelerin finansman tercihlerini, genişleyici para politikası sonucunda düşen faiz oranlarını da göz önünde bulundurarak, borçlanma yönünde kullanmaları beklenmektedir. İşletmeler farklı para birimleri üzerinden borçlanma fırsatlarına sahip oldukları için oluşturulacak modele alternatif para birimlerinin faiz oranları da eklenmelidir. Bununla birlikte yabancı para birimi ile borçlanmanın riskini temsil edecek olan yabancı para birimlerinin değerlerinin de modele katılması uygun olacaktır. Diğer taraftan, Tobin q teorisi çerçevesinde yatırıma yönlendirilebilecek fonların artması sonucunda hisse senetlerinin değer kazanması ve işletmelerin de bu değer artışından faydalanabilmek için finansman tercihlerini hisse senedi ihracı yönünde kullanmaları da beklenmektedir. Ayrıca işletmelerin girdi maliyetlerini etkilemesi açısından döneme ilişkin üretici fiyat endeksi beklentilerinin de modele katılması yararlı görülmektedir. Böylece üretici fiyat endeksine ilişkin beklentilerin, şirketlerin finansman tercihleri üzerindeki olası etkileri de gözlemlenebilecektir. İncelenen dönem tüm dünyayı derinden etkileyen ve etkisi hala devam eden büyük bir kriz dönemini içerdiği için sisteme kriz dönemlerini temsil edecek kukla değişkenler eklenerek, krizin finansman tercihi üzerindeki etkisi ortaya koyulabilir.

Bu açıklamalar ışığında çalışmada test edilmesi planlanan model aşağıdaki gibidir:

$(\text { Borç/Öz Kaynak })_{i t}=a_{i t}+\beta_{1}(\text { Borç/Öz Kaynak })_{i t-1}-$ $\beta_{2}(\text { Faiz Oranı })_{\text {it }}-\beta_{3}(\text { Tobin q })_{\text {it }}+\beta_{4}\left(\text { ÜFE }_{\mathrm{E}}\right)_{\text {it }}+\beta_{5}(\text { Avro })_{\text {it }}+$ $\beta_{6}(\text { Dolar })_{\text {it }}+\beta_{7}\left(\text { Kukla }_{2008}\right)_{\text {it }}+\beta_{8}\left(\text { Kukla }_{2009}\right)_{\text {it }}+\varepsilon_{\text {it }}$

Modelde ele alınan "Borç/Öz Kaynak" oranı, borcun defter değerinin öz kaynağın defter değerine bölünmesi ile elde edilmiştir. "Faiz Oranı" olarak ağırııklandırılmış yıllık mevduat faiz oranları kullanılmıştır. "Tobin q" değeri hesaplanırken öz kaynağın piyasa değerine borcun defter değeri eklenmiş ve bulunan değer toplam aktiflerin defter değerine bölünmüştür. "ÜFE" değişkeni, yıllık üretici fiyat endeksidir ve enflasyon beklentisinin etkisini ölçmek için modele eklenmiştir. "Avro" ve "Dolar" değişkenleri, yılsonu döviz kuru pariteleri ile döviz mevduat faiz oranlarının çarpımı yoluyla elde edilmiştir. Bu nedenle, yabancı para cinsinden borçlanma alternatifine sahip işletmelerin finansman yöntemi olarak bu kanalı kullandıklarında karşılaşabilecekleri döviz kuru ve faiz riskini birlikte içermektedirler. "Kukla ${ }_{2008}$ " ve "Kukla ${ }_{2009}$ " değiş̧kenleri incelenen dönem içinde yaşanan krizin etkilerini gözlemlemek amacıyla modele eklenmiştir. Verilerin test edilmesinde önceki döneme ait borç/öz kaynak 
yapısının izleyen dönemin borç/öz kaynak yapısı üzerinde etkili olabileceği ihtimalinin de değerlendirilebilmesi için Arellano-Bond dinamik panel veri tahminleme yöntemi kullanılmıştır.

Çalışmada, Türkiye Finansal Raporlama Standartlarına (TFRS) uygun olarak finansal tablo hazırlayan ve hisseleri İstanbul Menkul Kıymetler Borsası'nda (IMKB) işlem gören işletmeler ele alınmıştır. İncelenen dönem 2003-2010 yılları arasını kapsamaktadır. ${ }^{4}$ Ayrıca finansal tablo formatlarının ve uygulamakla yükümlü oldukları düzenlemelerin farklı olmasından dolayı finans sektöründe faaliyet gösteren işletmeler örnekleme dâhil edilmemiştir. Döneme ilişkin olarak toplamda 1343 adet gözlem elde edilmiştir. Borç/Öz Kaynak ve Tobin q değişkenlerini hesaplamada kulIanılan değerler, işletmelerin finansal tablolarından elde edilmiştir. Modelde kullanılan diğer değişkenler, TC Merkez Bankası'nın elektronik veri dağıtım sisteminden elde edilmiştir. Tobin q hesaplanmasında kullanılan "öz kaynağın piyasa değeri" tutarları IMKB'nin internet sitesinde sunulan verilerden toplanmıştır.

\section{BULGULAR}

Çalışmada kullanılan modelin test edilmesi sonucunda elde edilen bulgular Tablo 1'de sunulmaktadır. Bu bulgular ışığında bağımlı değişkenin gecikmeli değerinin istatistiki olarak anlamlı olmadığı tespit edilmiştir. Diğer bir ifadeyle, işletmelerin yeni finansman kararlarını alırken geçmiş finansman tercihlerinden etkilenmedikleri söylenebilir. Bu durumda işletmelerin yeni finansman arayışlarında kalıplaşmış uygulamalara yönelmedikleri ve sabit fikirli olmadıkları, geçmiş senelerdeki borç/öz kaynak yapılarının izleyen yıllarda yapılabilecek finansman karması kararlarını etkilemediği söylenebilir.

Diğer bağımsız değişkenlerden olan, Tobin q'nun, bağımlı değişken üzerinde anlamlı bir etkisi bulunamamıştır. Bu da para politikası ile sermaye yapısı arasında Tobin q üzerinden oluşabilecek ve/veya açıklanabilecek olası bir ilişkinin bulunmadığını göstermektedir. Bu durumda işletmelerin, sermaye yapılarının belirlenmesinde hisse senetlerindeki aşırı değerlenmeleri göz önünde bulundurmadıklarını söylemek olanaklıdır.

Faiz oranı değişkeninin, istatistiki olarak anlamlı çıkması işletmelerin finansman kararlarında Türk Lirası faiz oranını hesaplarına kattıklarının göstergesidir. Öte yandan değişkenin katsayısının 0.06 gibi çok düşük bir değer aldığı için incelenen dönem içinde geleneksel faiz kanalının çok güçlü bir kanal olmadığı söylenebilir.
Tablo 1: Genelleştirilmiş Moment

Yöntemi ile Analiz Bulguları

\begin{tabular}{|l|l|l|l|}
\hline & Katsayı & Std. Hata. & $P>|z|$ \\
\hline B/Ot-1 & $-0,092092$ & 0,1229401 & 0,454 \\
\hline Tobin Q & 0,0453019 & 0,0637954 & 0,478 \\
\hline Faiz Oranı & $-0,0633716$ & 0,0264547 & 0,017 \\
\hline Üfe & $-0,0203181$ & 0,0073924 & 0,006 \\
\hline Avro & 1,200916 & 0,3755752 & 0,001 \\
\hline Dolar & 0,8279835 & 0,5019286 & 0,099 \\
\hline Kukla $_{2008}$ & $-0,4388184$ & 0,2697339 & 0,144 \\
\hline Kukla $_{2009}$ & 0,3604499 & 0,1276439 & 0,005 \\
\hline Sabit & $-3,97063$ & 1,449647 & 0,006 \\
\hline
\end{tabular}

Fiyat beklentilerinin etkilerini gözlemlemek için modele eklenen üretici fiyat endeksi değişkeni de istatistiksel olarak anlamlıdır. Üretici fiyat endeksindeki yükselmelerin girdi maliyetlerini artırması, bu nedenle işletmelerin fiyat artışından kaçınabilmek üzere erken borçlanma eğiliminde olmaları beklenmektedir. Diğer bir ifadeyle, ÜFE artışının ilgili dönem için borçlanmanın finansmandaki payını artırması beklenirken bu değişkenin işaretinin beklenenin aksine negatif olması şaşırtıcıdır. Bu durum, teorik olarak rasyonel bekleyişler teorisi ile açıklanabilir. Rasyonel bekleyişler teorisine göre, tam bilgiye sahip olan ekonomik birimler üretici fiyat endeksindeki artışa merkez bankasının faiz oranını artırarak cevap vereceğini bilirler. Bu durumda yükselen faiz oranlarından borçlanmaktan kaçınacaklar ve Borç/Öz Kaynak oranı azalacaktır. Teorik bir alt yapı ile açıklanabilen bu ilişkinin işletmeler tarafından kullanıldığını düşünmek oldukça iyimser bir durumdur. Fakat çalışmanın bulguları işletmelerin uygulamada bu tür bir akıl yürütme sürecini takip ettikleri düşüncesini desteklemektedir.

Döviz kuru ve faiz oranı risklerini temsil etmesi için modele eklenen Avro ve Dolar değişkenlerinden Avro değişkeninin istatistiksel olarak anlamlı olduğu ve işletmelerin yeni finansman kararlarında avro riskinden kaynaklanabilecek durumları hesaba kattıkları açıkça görülmektedir. Bununla birlikte Dolar riskini temsil eden değişkenin \%5 güven aralığı düzeyinde istatistiksel olarak anlamsız çıkması işletmelerin incelenen dönemde borçlanma aracı olarak bu değişkeni karar almakta kullanmaktan sakındıklarına işaret etmektedir.

2008 'in ikinci yarısından itibaren dünya genelinde hissedilen ekonomik krizin, işletmelerin olası finansman tercihleri üzerinde etkilerini ortaya koymak için modele eklenen kukla değişkenlerden 2008 yılını temsil eden değişkenin $\% 5$ güven aralığı için istatistiksel olarak anlamlı olmadığı görülmektedir. Bu durumda küresel ekonomik krizin işletmelerin 2008 yılı 
finansman kararlarına etki etmediğini savunmak olanaklıdır. Bununla birlikte 2009 yılını temsilen modele eklenen kukla değişkenin istatistiksel olarak anlamlı olduğu ve işletmelerin finansman kararları üzerinde göz ardı edilemeyecek oranda etkisi olduğu açıç̧a ortadadır. 2009 yılında küresel ekonomik krizin etkileri daha derinden hissedilmeye başlanmış ve işletmeler de finansman kararları gibi önemli kararlarında bu krizin olası etkilerini hesaba katmışlardır.

\section{SONUÇ VE DEĞERLENDIRME}

Bu çalışmada para politikası değişikliklerine paralel olarak işletmelerin finansman yöntemi tercihleri geleneksel faiz kanalı ve Tobin q teorisi kapsamında incelenmiştir. Genişleyen para politikası sonucunda düşen faiz oranlarının işletmeleri borçlanmaya yönlendirmesi beklenmektedir. Ayrıca genişleyen para politikasının diğer bir sonucu olarak artan para arzının yatırıma yönlendirilebilecek fonlarda artış yaratmasının hisse senetlerinin değerini artırması beklenir. İşletme performansından kaynaklanmayan bu artışı hisselerin aşırı fiyatlanmış olduğunun bir göstergesi olarak kabul eden Tobin q teorisine göre işletmelerin finansmanda yeni hisse senedi ihracına yönelmeleri beklenmektedir.

Bu teorik altyapı çerçevesinde oluşturulan modelin dinamik panel veri analizi ile test edilmesi sonucunda geçmiş dönem borç/öz kaynak değerlerinin ve Tobin q değişkenlerinin olası finansman kararlarında etkili olmadığı ortaya konulmuştur. İşletmelerin, yeni finansman kararlarında hisse senetlerindeki aşırı değerlenmeleri göz önünde bulundurmadıklarını söylemek olanaklıdır. Bu da Tobin q teorisinin incelenen dönemde işletmeler için çalışmadığını göstermektedir. Tobin q göstergesinin beklenen etkiyi yansıtamamasının olası nedenleri arasında işlem maliyetlerinin yüksek olması, hisse senedi ihracı sürecindeki bürokratik işlem yoğunluğunun çok olması ve hisse senetlerinin beklenen fiyat seviyesine çımaması sayılabilir. Ancak, daha net bir yorumun yapılabilmesi için söz konusu nedenlerin de modellerde ele alınması gerekmektedir. Hisse senedi ihracına ilişkin nedenlerin yanı sıra işletmelerin finansal tablolarında sundukları tutarların gerçeğe uygun değer yerine tarihi maliyet esasına göre raporlanmış olması olasılığı da göz önünde bulundurulması gereken bir husustur. Çalışmada Tobin q değerinin hesaplanmasında varlıkların ve borçların defter değerlerinin kullanılması nedeniyle, bu olası durum Tobin q göstergesinin beklenen etkiyi yansıtmamasının nedeni olabilmektedir.

Oluşturulan modelde Türk Lirası faiz oranı, üretici fiyat endeksi, Avro kaynaklı borçlanma riski ve 2009 kriz kukla değişkenlerinin işletmelerin finansman kararlarında etkili oldukları görülmektedir. Para politikası etki kanalları arasında en geleneksel ve doğrudan olan faiz kanalının işletmelerin finansman kararlarında etkili olduğu görülmekle birlikte, Türk Lirası faizi kanalının kuvvetli bir kanal olmadığı rahatlıkla söylenebilir. Öte yandan, yine geleneksel faiz kanaIından çalışan Avro ile borçlanma kanalının incelenen dönemde işletmeler tarafından daha fazla ciddiye alındığı ve bu kanalın finansman tercihleri üzerinde belirgin bir etkisi olduğu açıktır. Kısacası, geleneksel faiz kanalı çalışmakta, fakat Avro üzerinden çalışan kanalın Türk Lirası üzerinden çalışan kanaldan daha kuvvetli olduğu görülmektedir.

Bu çalışmada, bulguların değerlendirilmesi sonucunda iki önemli sonuç saptanmıştır. Bunlardan ilki, geleneksel faiz kanalı içinde değerlendirilen Avro kaynaklı risklerin azaltılmasının işletmelerin borçlanmalarını kolaylaştırdığıdır. Bu durumda Avro değerindeki dalgalanmaların azaltılması işletmelerin risk algılarını azaltarak borçlanma kanalı aracılığıyla yapacakları yeni yatırımlar konusunda işletmeleri cesaretlendirecektir.

İkinci önemli saptama ise ekonomik krizlerin önemi üzerinedir. Ekonomik krizin işletmelerin sermaye yapısı üzerindeki etkilerinin göz ardı edilemeyecek kadar belirgin olduğu görülmektedir. Bu nedenle, krizin etki süresinin belirlenmesi ya da derinliğinin ölçülmesi üzerine çalışmalar da yapmak olanaklıdır. Benzer veri setleri kullanılarak yapılabilecek ilerleyen çalışmalarda, ekonomik krizlerin etkilerinin de göz önünde bulundurulması gerekli görülmektedir. 


\section{SON NOTLAR}

${ }^{1}$ Diğer parasal aktarım kanalları için bkz. Mishkin, 1996.

2 Ülkemizde TFRS’nin (ihtiyari olarak) uygulamaya geçildiği yıl olması açısından 2003 yılından itibaren yayınlanmış yıllık finansal tablolar analize dahil edilmiştir. İhtiyari uygulama olması nedeniyle analize katılan 2003 ve 2004 yıllarına ait finansal tablolar sadece TFRS'yi uygulamayı tercih eden işletmelerin finansal tablolarından oluşmaktadır.

\section{KAYNAKLAR}

Akkaya, G.C. (2008) “Sermaye Yapısı, Varlık Verimliliği ve Karlıllk: İMKB'de Faaliyet Gösteren Deri-Tekstil Sektörü İşletmeleri Üzerine Bir Uygulama” Erciyes Üniversitesi İktisadi ve İdari Bilimler Fakültesi Dergisi, 30:1-13.

Ata, H.A. ve Ağ, Y. (2010) "Firma Karakteristiğinin Sermaye Yapısı Üzerindeki Etkisinin Analizi” Ekonometri ve Istatistik, 11:45-60.

Baker, M. ve Wurgler, J. (2002) "Market Timing and Capital Structure" Journal of Finance, 57(1):1-33.

Bie, T. D. ve Haan, L.D. (2007) "Market Timing and Capital Structure: Evidence for Dutch Firms" De Economist (Springer), 155(2):183-206.

Buferna, F., Bangassa, F. ve Hodgkinson, L. (2005) "Determinants of Capital Structure Evidence from Libya" The University of Liverpool Research Paper Series, 2005/08:1-31.

Drobetz, W. ve Fix, R. (2003) "What are the Determinants of the Capital Structure? Some Evidence for Switzerland" WWZ / Department of Finance, Working Paper, No:4/03.

Easterbrook, F.H. (1984) "Two Agency-Cost Explanations of Dividends" The American Economic Review, 74(4):650-659.

Fama, E.F. ve French, K.R. (2002) "Testing Tradeoff and Pecking Order Predictions about Dividends and Debt" Review of Financial Studies, 15:1-33.

Frank, Z.M. ve Goyal, V.K. (2007) "Trade-off Pecking Order Theories of Debt" Handbook of Corporate Finance: Empirical Corporate Finance, 2(12):1-88.

Gupta, C.M. (1969) "The Effects of Size, Growth and Industry on the Financial Structure of Manufacturing Companies" Journal of Finance, 24:517-529.

Hovakimian, A., Opler, T. ve Titman, S. (2001) "The Debt Equity Choice" Journal of Financial and Quantitative Analysis, 36:1-24.

Jensen, M.C. (1986) "Agency Costs of Free Cash Flow, Corporate Finance, and Takeovers" American Economic Review, 76:323-329.

Jensen, M.C. ve Meckling, W.H. (1976) "Theory of the Firm: Managerial Behavior, Agency Costs and Capital Structure" Journal of Financial Economics, 3:305365.
Kayhan, A. ve Titman, S. (2007) “Firm's Histories and their Capital Structures" Journal of Financial Economics, 83:1-32.

Mahajan, A. ve Tartaroglu, S. (2007) "Equity Market Timing and Capital Structure: International Evidence" Journal of Banking and Finance, 32:754-766.

Miller, M.H. (1977) "Debt and Taxes" Journal of Finance, 32(2):261-275.

Mishkin, F.S. (1996) "The Channels of Monetary Transmission: Lessons for Monetary Policy” NBER Working Paper Series, No:5464.

Modigliani, F. ve Miller, M.H. (1958) "The Cost of Capital, Corporation Finance and The Theory of Investment" American Economic Review, 48(3):433-443.

Myers, S.C. (1977) "The Determinants of Corporate Borrowing" Journal of Financial Economics, 5:147-175.

Myers, S. C. (1984) "The Capital Structure Puzzle" Journal of Finance, 39:575-592.

Myers, S. ve Majluf, N. (1984) "Corporate Financing Decisions When Firms Have Information Investors Do Not Have" Journal of Financial Economics, 13:187-221.

Tian, H., Xi-juan, S. ve Xian-na, L. (2008) "Market Timing and Capital Structure: Evidence from Shenzhen Market in China" 4th International Conference on Wireless Communications, Networking and Mobile Computing.

Tobin, J. (1969) "A General Equilibrium Approach to Monetary Theory" Journal of Money, Credit and Banking, 1:15-29.

Uğurlu, M. (2000) "Agency Costs and Corporate Control Devices in the Turkish Manufacturing Industry" Journal of Economic Studies, 27(6):566-599.

Türkiye Cumhuriyet Merkez Bankası Elektronik Veri Dağıtım Sistemi (2012) http://evds.tcmb.gov.tr/cbt.html (Erişim: 14.03.2012)

Borsa İstanbul (2012) http://imkb.gov.tr/ FinancialTables/companiesfinancialstatements. aspx?sflang=tr (Erişim: 14.03.2012)

Borsa İstanbul Kamuoyu Aydınlatma Platformu(2012) http://kap.gov.tr/yay/ek/index.aspx (Erişim: 14.03.2012) 